\title{
Traditional Methods of Crime Control and Community Security in Odukpani Local Government Area of Cross River State - Nigeria
}

\author{
Ayuk, Awunghe Achu, Dr. Emeka Josephat Owan, Uyang, Francis Abul \\ Department of Sociology University of Calabar Calabar.
}

\begin{abstract}
The persistent increase and alarming rate of criminal activities experience recently in Nigeria is a cause for concern to all and sundry. This is a sharp contrast to the olden days when traditional methods and measures were used in controlling crime as against today's modern methods. Arguably the sophistication of weapon used by the security agents recently has not significantly reduced crime - this is because of the manifestation of the social disorganization in the normative system. Consequently, this presentation retrospectively $x$-rayed the traditional methods of crime control in Efik kingdom in Calabar, Cross River State, Nigeria. The work examined how crime and criminal related activities were addressed in the past with a view that if these methods can be applied contemporarily to arrest the meteoric rise in crime, its occurrence can be reduced in the present Nigeria since the modern or Western methods have not dealt with crime significantly. To explain the phenomenon of crime, anomic theory was considered and base on the findings the study recommends as follows: traditional methods should be encouraged to compliment the efforts of the government security agencies and the rituals aspect in the traditional methods that are repugnant to natural justice and offends morality should be jettisoned for collaboration to effectively check crime.
\end{abstract}

\section{Introduction}

For sometime now (past two decades) Nigeria society has been plagued with frightening crimes and often than not the consequences are devastating and appalling. This unsavoury development has generated a lot of concern amongst scholars, religious clerics, non-governmental organization and government (Emmanuel Iheajemuzu, 1997). This concern also has been expressed in the media (print and electronics), seminars, conferences, symposia - all in attempts to meet a common ground on its control.

It is understood that crime is the act of violating the law and equally a social problem that transcends generations and mankind - and characterized all known contemporary modern societies (Meveigh 1978). However, what constitute crime varies not only from society to society but from time to time as well as from strict enforcement to none. However, the focus of this work is not an exposition on crime, but to espouse on traditional methods, aside from the Western means (police, courts prisons etc) to control this menace that have robbed off society(al) peace in Nigeria (Ayuk, 2012).

Before the advent of Western civilization and penal system to Africa and indeed Nigeria, traditional African societies had means of social control, reformation and moral cleanser which served then as instruments to correct and serve justice. Accordingly, Ezenibe (1999) opined that these traditional methods (like in Odukpani community include Mbiam (oath), Uwang (tying of palm front), Uyere nkang (rubbing of charcoal) of crime control were means the society used to encourage conformity to norms and values.

There were various channels traditionally through which societies controlled crime. This includes the elders councils, chiefs, village heads etc; whose functions was the interpretation of the code of conduct and behaviour of the subsisting community as pass down from generations to generation. It is a fact that traditional societies did not have written laws to guide conduct as observed in and by the western societies, but it had a well established institutions for controlling crime and maintaining social order.

In modern societies, legislative bodies make laws, the executive implement the laws while the judiciary interprets. As of old, there were no clear cut distinction vis-à-vis division of labour as to who should handled what or not. At the same time no society has ever existed without rules, customs and laws that explains government relationship between individual and group (Clifford 1984). To this extent, the traditional methods of crime control, though primitive as it were, were very useful in the true sense of it, but as the society become more complex via industrialization and urbanization, the traditional institutions became increasingly disengaged from the process of maintaining law and order (Akintola, 1982).

Since crime has become as complex as human nature and the western penal system which is now preferred to controlling crime has done little or nothing to addressing this societal hiatus, it is therefore apt to synergize the two divide in crime control. Depending on the western penal systems in Africa (Nigeria) and 
given that judgement and convictions are always delayed, the tendency is that justice would not always to the extent that be served and to the extent that criminals are set free.

More worrisome is how modern technological advancement and tremendous progress in communication have facilitated crime and most time, the modern methods cannot expressly point to, as what is criminal - this has adversely affected the society, by hampering the quality of life to be lead and threatening human rights to freedom. No community has remained unaffected, by the negative consequences of crime, although the level and intensity of the problem might vary from community to community. This work is principally geared toward $\mathrm{x}$-raying how traditional methods of crime control were effectively administer to control crime until the adoption of the western system (values) and to prove to what extent borrowed cultures have undermined Africa's structure and basis of or for social control.

\section{Background To Traditional Methods Of Crime Control}

Traditional methods of controlling crime and maintaining security is not of universal acceptance as it is culturally relative. These ways to a great extent have to deal with pattern of organization and belief system of the people. (Box 1987). When people are bound together by strong cohesive bounds of community consciousness, well tribal transaction, crime can be reduced to a bearest minimum (Box 1987 \& Dambazau, 1994).

Traditional crime control, indeed the prevention and control of criminal behaviour in Nigerian communities has its roots in kinship and extended family system. Within the lineage group, the leader of the group, usually the eldest male person provides the examples as he is the model of conduct. Above the lineage group, are the clans in which authority is subordinated to, that of a figure; who is not merely a model of conduct, but also conducts ceremonies which affirms the corporateness of the people and moreover armed with the power of sanctions against offenders.

For example, among the Igbo extraction of eastern Nigeria, each lineage system is made up of a number of territorially kin-based units. Each unit is made up of economically independent household and each household recognized the authority of the compound head. The compound head has numerous rituals, moral and legal rights and obligation. He offers sacrifices for the welfare of his compound members, whom he helps to extricate from the ritual, social and legal problems (Dambazu, 1994).

The system of organizing the family in the pattern of kinship and extended family is significant in understanding crime prevention and control in the traditional Nigerian setting. Control of member of a family was simple, but effective and in most cases, democratic. The family which was the source of stability and social control was united under the control of the oldest person. But modernity has affected the kinship and extended family system, and social control is no longer the same.

Religion (especially Africa traditional religion) was also regarded as one best way in controlling crime in the society (Africa). Religion may be viewed in a narrow sense to refer to a set of theological beliefs held and rituals performed by members of a particular group. In a broad sense it involves the integral part of culture of the people. The etymological meaning of religion point to its social function of discipline which this study contextualizes.

Durkheim (1961) viewed religion as unified system of beliefs and practices relative to sacred things, (things set apart and forbidden) beliefs and practices which unite into one single moral community. While turner (1993) sees religion as the control of men by the establishment of rules which create mutual obligations in order to cement social relationship. Mankind would lie in a deplorable state if no principles or precepts of justice, veracity and beneficence were not taught privately or publicly - opposite vices would steal the shine (Colcord, 2003).

The argument that religion is an important tool for the moral well-being of the community has been advanced in many forms. One of such is that, religion is useful as a cohesive factor, holding the society and its morality together in such away that whoever attacks the society's religion is deemed to have attacked the society. Religion has also been seen as a source of strength and consolation, and essential for moral education, moral endeavour and moral achievement (Akiba, 2012).

Giving that African societies are relatively undifferentiated and homogenous and religiously dispose, meaning that religion governs our lineage and family relationship; religion means collectivity, and forms the basis of social control (Akiba, 2012). It was the religious ties that created propitious leverage for strong community ties and less crime in Africa traditional societies. In relation to criminal behaviour, religion has expressingly sort to solving integratively these problems, because it legitimizes our values and provide reasons why certain values should be preferred to others (Ayuk, 2012).

For instance, Oba (2006) argued that the use of curses to compel people to respect their taboos and laws served as a control. Curses were generally feared because of the belief that defaulters would be inflicted with protracted sickness, sudden death or other calamities. However, irrespective of the means used, certain 
agents and means of crime control have come to be commonly identified by this direction. Among the widely used in Africa (Nigeria) are association like age - grades, social clubs and vigilant groups.

Omagu (1979) observed that, age - grade organization played very significant role in the socio-cultural life of the people. It performed both social and political functions; and inculcate healthy ideas and objectives in their members and further act as a disciplinary body for erring members. This was done by subjecting such members who violate the societal (social) norms to sanctions and punishment. Talboth (1999) buttresses this assertion and noted that age - grades are very essential in the chain of government and without them the administrative function could hardly be carried out. Specifically age - grades look after roads maintenance and other developmental projects - others act as police in the community. Another method employed traditionally in crime control is the vigilante groups who act as police in the various communities they subsist. They are watchmen, guards, members of the communities are organized to suppress and punish crime summarily as when the process of law appears inadequate as the case with Nigeria.

\section{Machineries Of Crime Control Among The Efik People}

Since the Efik people of Cross River State, Calabar - Nigeria traditional society lacked laws defined in terms of authority and court, such as found in today modern judicial system, there existed several agencies that played significant roles in maintaining social order in their domain. These agencies are; Ekpri Akata, Ekpo society, Nka (age grade), Iban Ison. They assist in no small measure in crime control in the Efik traditional society. Their roles and mode of operations are discussed below.

\section{a) EKPRI AKATA}

This is a male dominated and oriented group whose concern was to maintain moral sanctity of the society. It became one of the strongest forces of correction and moral cleanser in Efik kingdom. Its members were regarded as "spirit" and thus dispose clairvoyantly to all sort of crime and scandals committed in the society (Akak, 1982).

The primary functions of Ekpri Akata were therefore the detection of anti-social behaviour, exposing those who commit crime and ridiculing them into correction. Members usually meet at night to gossip about misbehaviour and immoral acts of individual or groups in the community. With disguised voice members move around the village in the cause of moral crusade. Young girls who attempted abortion, those who stole as well as men and women found committing adultery were the greatest targets and victims. They use songs to rebuke and method of gossip to expose so many unholy practices of members of the society. Ekpri Akata was a mouth piece of the public concerning secret happenings in the village. It exposes criminals, witchcraft, theft etc. This crusade was very necessary and useful as means of riding of the society of immorality, illegality and slander.

\section{b) Ekpe Society:}

Ekpe culture is the highest of all traditional institution in Efik kingdom. Ekpe culture was the instrument of government which is most revered, renowned and most powerful in the society. Ekpe society was by far the most important institution that wielded so much power in the formulation and enforcement of traditional authority in Efik land. This assertion was corroborated by Oku (1999), that politically, economically, culturally and even legislative and judicial roles covers the jurisdiction of Ekpe society cult.

Ekpe society settles major conflict/disputes and cases involving individual, group and cases between one Efik clan and other; parties were made to pay fines if found guilty. It judgment concerning any matter of disputes or whatever was final. Hart (1964) maintain that Ekpe's sanctions could be enforced in several ways, viz:

i) preventing the movement or use of culprit's property;

ii) by confining offender(s) to their homes;

iii) offenders are made to swear to Mbiam Ekpe (its oath) of which can lead the culprit to sudden death by swelling if guilty.

\section{C) EKPA CULT}

This is the female cult and it serves as a social reformer group which usually organize her members to sing and dance only at night amongst themselves rebuking social ills and warning males in the community against disrespect for womanhood. It also had power over men who insult or abuse women in abominable manner. Men who abuses their wives are often ridicule or abuse with or in songs and sometimes made to pay fines or inflict whatever punishment they so desire on such men. Women found to be adulterous and who commit abortion were equally punished accordingly (Oku, 1982). 
d)

IBAN ISONG

The Iban group in Efik land and members were mostly of old women. Their functions were aimed at sustaining discipline and rejecting immoral acts, irresponsible behaviour and utterances. They serve to protect the integrity of women by training them in moral and domestic responsibilities and upholding the moral value/virtue of the Efik people and the society (Hart, 1964). This group does not tolerate indiscriminate utterances or black mail of the women. In extreme situations they usually sing and dance nude before the offenders.

This cult exercise unquestionable authority over affairs of women in the community with the fundamental objective of protecting the decency of womanhood. Akak (1982) observed that their laws are usually harsh on women who stole in the market places or farms. When caught, their hands and feet tied and mouth stuff with dirt - in extreme cases the culprit's body will be painted with charcoal and paraded before the public. The offender could also be banned from future participation in the affairs concerning women in the village.

\section{Traditional Measures In Crime Control In Efik Land}

The Efik people had various measures of crime control and these suit the purpose of the time and help in the maintenance of social order in their domains. These include:

a) ABIAM (OATH TAKING):

This involves oath taking by swearing to "Juju" or "Mbiam". Suspects were made to swear by "mbiam" to ascertain their innocent or guilt. The "mbiam" was so potent and effective that people were scared to commit crime - because of it resultant effect of sudden death by swelling.

\section{b) UWANG (TYING OF PALM FRONT LEAFS):}

This measure was most effective as it scared people from stealing "uwang" was usually hung on tress, fruits or on farmlands to prevent people from trespassing farmlands, steal or harvest any fruit without the owner consent (Oku, 1982).

\section{c) UYERE - NKANG (RUBBING OF CHARCOAL):}

This is an equivalent of the present day practice of parading suspect before the public using mass media. A person caught red handed in the act of crime was paraded stark naked with charcoal rubbed and made to dance round the whole village. The shame associated with "uyere - nkang" compels would be criminal to suppress their criminal tendencies.

\section{Public Denouncement}

Hart (1964) observed that public denouncement was radical measure in crime control among the Efik people. It carries with it some economic sanctions which might prevent the offenders from engaging in any type of economic relationship with any person in the village and nobody will buy from you (offender) or neither sell anything to you (offender) - or talk to the offender in the village. Public denouncement served as deterrent to people intending to commit crime and make others to abstain from such acts.

\section{Indemnification Control Measure}

This method was used interchangeably with obstracism as a measure of crime control amongst the Efik communities (Oku 1982). This is applied to criminal cases like homicide, fratricide, matricide, patricide or betraying one's own community especially in time of war. The criminal in this case is banished for life or for a period of time. Sometime the offender is compelled to pay compensation as a punishment for what he/she has done. In most cases the victim's close relative is usually put to death or use for sacrifice to appease the gods of the land. It serves as deterrent to others.

\section{Praise And Blame}

The Efiks believed that in praising and rewarding good behaviour or achieving marvelous deeds served as motivating template for the person and society at large. Good conduct were encouraged, similarly bad conduct were openly denounced by blame (Akak 1982). This measure (praise and blame in Efik land) in crime control help in maintaining of social order and ensured conformity then.

\section{Reparation/Restitution}

This approach suggest that the victim should be restored to his status - quo ante or former position. This applies prepondently in civil case but could be accepted in criminal cases like compensation. 


\section{Theoretical framework}

The cultural relativity of crime and multiplicity of competing explanation of crime have led to series of approaches concerning crime, it causes and control. Some of this approaches have yielded more questions than answers. The lack of consensus and the controversy generated have led sociologists, historians, philosophers, legal thinkers, politicians and other thinkers to develop various theories for the explanation of crime, causes and control.

Most of these ideas are tied to an existing level of knowledge of that period as interest and concern in crime control and dated back to the earliest traces of human civilization. For instance when people accepted the existence of witches, wizards and evil spirit, anyone who deviated from such beliefs was said to be possessed, and was either stoned to death or left in the forest to die. Now, with the advances in medical sciences, criminal are now diagnosed and viewed as sick and therefore amendable for treatment. This study therefore considers the anomic theory to explain the causes of crime and its control in the society.

\section{Concept Of Anomies Solidarity And Crime In Traditional African Society}

Anomie is a state of lack of social norms which describes the breakdown of social bonds between individual and amongst groups. It could represent a situation that conjures absence of usual social or ethical standards in individual or group. Furthermore, anomie is said to be a condition of instability and insecurity resulting from the breakdown of standard and values.

Simply, anomie is a state of normlessness and generally happen in periods of fast paced changes, when norms of existing society cannot keep up with the pace of life. It is sort like cultural lag (Britannica.com/../anomie).

In the context of crime control and insecurity challenges, anomie refers to personal isolation and anxiety resulting from lack of social control and regulation (antisocial behaviour). Anomie in the traditional African society run rampant today due to several extraneous influences viz; borrowed western culture as expressed in their institutional build-up (court, police, prisons etc), telecommunication, internets, movies etc which persistently where unAfrican (Ayuk, 2013).

These injections to a large extent dislodged the original held beliefs and bonds that defines Africa's tenets. Sadly these cherished values that characterized social control mechanism in Africa have become relics and historical rites. No wonder, crime and criminal activities has remained on the increase to the extent that, the police and other security outfits cannot arrest.

Emile Durkheim, maintained that when society do not regulate the individuals sufficiently, untoward behavior emerges and this occurs when traditional norms and values are disrupted by rapid social change, which produced uncertainty in the minds of individuals as society's guideline for behaviour become increasingly unclear (Haralambos \& Holborn 2009). Equally Foucault (1924 - 1984), a French philosopher, social theorist argued that power has the ability to control knowledge and can be used as a form of social control. Impliedly with well defined power structure, crime and insecurity problem can be adequately checked. For him the preponderance of insecurity and crime is the inability of power to effectively exert control in the polity.

Similarly Durkheim (1961), observed that the existence of collective conscience exerts strong influence on people in preindustrial societies. People felt sense of solidarity because they were similar to one another (organic solidarity). Hence there was social control. But as the society evolves, division of labour becomes specialized, people no longer behave similar to one another and social control became nearly impossible and value jettisoned, which forms the basis for normlessness.

Hence, for social control to be meaningful the lost collective conscience, (organic solidarity) must be restored, i.e, those shared cultural values that guarantees harmony and encourages synchronization of relationship collective and existence must be emphasized.

\section{Anomic Theory:}

The major proponents include: Emile Durkheim, Herbert Spencer, Talcott Parson, Robert Merton. Emile Durkheim had once posited that in primitive societies there existed mechanical solidarity where mores and folks flores control people's behaviour. But as society gets larger and more complex - their was a shift from mechanical to organic solidarity resulting to increase in division of labour and heterogeneity. The result is that the traditional forms of social control was rendered ineffective. Consequently, anomic and normlessness replaces the former state of solidarity. Under this condition, individuals strive to reach their goals by the most effective means readily to them regardless of the moral prohibitions of society, hence, high rate of deviant behaviour.

Merton elaborated on the anomic theory by suggesting that all social structure have goals and means. But in a state of anomic where these goals and norms are rejected or the means for obtaining them are rejected, deviant behaviour holds sway; but if these goals are maintained order is achieved in such setting. 
This theory aptly explains why crime is on the increase. That people (Nigerians) have rejected these traditional means of crime control, while the police and other security agencies instead of carrying out their constitutional roles have resorted to sharp practices. (The bribe, extra judicial killing, robbery etc), the result is that crime and criminal activities are on the increase.

\section{Summary And Conclusion}

The study has its focus on the traditional methods of crime control among the Efik people (Creek town, Eniong and Okoyong). These communities employ the following traditional methods in crime control; viz; Ekpri Akata, Ekpe, Iban Isong, Uyere Nkang.

Chiefs/elders as observed contribute immensely to the control of crime and security in the areas. Offenders now are handed over to the police for further prosecution in the present setting. Traditional method of crime and security among the Efik people arguably people has undergone several changes as revealed from the research in both pre-colonial and present era, as against the past. For example these groups then perform functions like political, economic and social function. Presently all of these functions have been taken over by the government agencies. These changes came as a result of the introduction of Christianity, western education and colonialization and globalization has which brought about new system of government.

\section{Recommendations}

On the strength of what the research exhumed, the following recommendations were made;

Traditional methods of crime control should be encouraged to complement the effort of the security agencies - but the rituals aspect that are repugnant should be jettison to natural justice in order to gain the confident of government and the people.

Vigilante groups, Ekpe cult and other traditional groups should hand over culprits to constituted authorities and not to take the law in their hands (Jungle Justice).

\section{References}

[1]. Akak, E. O. (1982). Efiks of old Calabar culture and superstition Calabar. Akak and Publishers - Calabar - Nigeria.

[2]. Akintola, A. (1982). The law is for all fourth dimension. Publishers: Enugu - Nigeria.

[3]. Aye, E. U. (1967). Old Calabar through the century. Calabar Hope Waddell Press.

[4]. Ayuk, A. A. (2012). Security Parody: A paper presented on the inauguration of the Executive of National Social Work Student University of Calabar. Unpublished.

[5]. Box, S. (1983). Recession crime and punishment. London: Macmillan Books.

[6]. Clifford, W. (1974). An introduction to Africa criminology. Nairobi, Oxford University Press.

[7]. Colcord, G. (2003). Crime and corrections. Addison Wesley. New Jersey.

[8]. Dambazau, A. B. (1994). Law and criminality in Nigeria: An analytical discuss. Ibadan: University Press - Nigeria.

[9]. Durkheim, E. (1961). The elementary forms of religion life. New York: Macmillan Books.

[10]. Durkheim, E. et al (1963). Primitive classification, Cohen and West, London.

[11]. Ezenibe, S. U. (1999). The nature of crime and delinquency: An introduction. Seasprint Publishers: Calabar - Nigeria.

[12]. Emmanuel, O. N. (1999). The impact of vigilante group. Nigerian Chronicle. November 26 p.12.

[13]. Haralambos \& Holborn (2000). Sociology: Themes and perspective. Harper Collins, London.

[14]. Oku, E. E. (1980). The kings and critics of old Calabar (1885 - 1925). Calabar: Hope Waddell Printing Press.

[15]. Omagu, C. (1970). The morality of punishment. London: Kegan Paul.

[16]. Talboth, P. A. (1990). The people of Southern Nigeria. London.

[17]. Merton, R. K. (1971). Contemporary social problems. New York: Harcourt Brace Jovanovich. 